\title{
Cofradías y asociaciones religiosas en el Derecho actual
}

\section{INTRODUCCIÓN}

Las cofradías y asociaciones católicas, integradas en su mayoría por laicos, han decaído en los últimos tiempos y necesitan actualizarse, incluso entre los agustinos, pues se trata de poner en práctica un derecho fundamental de los fieles, como es el de la libre asociación dentro de los fines propios de la Iglesia; según se establece en el c. 215 del actual Código de Derecho Canónico. Los fines de las asociaciones se especifican en el 298 \& 1, donde se habla de obras de piedad, caridad, culto etc., como luego veremos. El concepto de cofradía, su espiritualidad, historia y función social han sido expuestos ampliamente en algunos congresos y encuentros de cofrades, presentando datos valiosos de los estatutos y modo de actuar los cofrades, que pueden servir de orientación y de fermento renovador ${ }^{1}$. Antes de entrar en la parte jurídico-canónica se da la evolución histórica de las cofradías y asociaciones religiosas.

\section{a) Las asociaciones y cofradias hasta el Concilio de Trento}

Las asociaciones cristianas datan de los primeros siglos. Un ejemplo lo tenemos en los colegios funerarios cristianizados, que ayudaron mucho en la época de las persecuciones. Los colegios romanos y las ghildas germánicas sirvieron de cauce legal a las confraternidades y gremios de los cristianos con distintos nombres, incluso algunos de penitentes ${ }^{2}$.

1. H. DuRAND, "Confrérie", Dictionnaire de Droit Canonique (DDC) 4 (París 1949) col. 128-75; A. DÍAZ Y DíAZ, Derecho fundamental de asociación en la Iglesia (Pamplona 1972); L. MARTÍNEZ SistaCH, El derecho de asociación en la Iglesia (Barcelona 1973); H. Schnizer, "Die kirchlichen Vereine", Handbuch des Katolischenrechts (Regensburg 1983) 444-76; VARIOs, Asociaciones canónicas de fieles (Salamanca 1987); VARIOs, Actas, Primer Congreso Nacional de Cofradías de Semana Santa (Zamora 1988); F. CAMPo DEL POZo,-"Cofradía de la Concepción Purísima de Mucurubá", Archivo Agustiniano 72 (1988) 159-218.

2. A. García García, "El asociacionismo en la historia de la Iglesia", Asociaciones canónicas de fieles, 21-23. 
El Derecho de la Iglesia ha prestado siempre atención a este fenómeno de las asociaciones religiosas o cofradías, que dieron origen a no pocas congregaciones y archicofradías durante la Edad Media. En los primeros siglos solían predominar en ellas los clérigos y monjes, lo mismo que las vírgenes, viudas etc. Luego predominan los laicos.

Al exponer este tema, como todo el Derecho Canónico, tenemos que mirar al misterio de la Iglesia ${ }^{3}$, desde su fundación, con un papel muy importante de los fieles cristianos. La Iglesia nace en el monte Calvario, cuando Cristo siendo Dios y Hombre muere para redimirnos y nos deja a su Madre como Madre nuestra. María es Madre de Dios y Madre de la Iglesia apostólica. Con una Madre espiritual nos sentimos hermanos y surgen las hermandades, siendo Cristo nuestro hermano mayor y cabeza.

La jerarquía eclesiástica ha procurado controlarlas y ya en algunos concilios y sínodos se prohibió su establecimiento sin la autorización del obispo. Proliferaron las asociaciones religiosas al lado de los conventos, según testimonio de Hincmaro de Reims (852) en sus Capitula ${ }^{4}$. Algunas asociaciones presentaron problemas como se ve en el concilio de Nantes (852) estableciéndose que no se fundasen sin el permiso del obispo diocesano y del señor del lugar, como se hace en el concilio de Ruán el año de $1189^{5}$.

Durante la Edad Media, a partir del siglo XIII, dependiendo de las Órdenes mendicantes, surgen las Órdenes terceras, como la franciscana, cofradías, archicofradías, pías uniones, sodalicios, congregaciones y hermandades, junto con gremios bajo un santo patrón. Se multiplicaron también en las parroquias las hermandades en torno a la Santa Cruz, la Eucaristía, la Santísima Virgen, los santos y las benditas ánimas. Ya en la Edad Media tenemos asociaciones penitenciales para promover el culto a la Pasión del Señor y la penitencia cuaresmal o de Semana Santa. Hubo algunas asociaciones de carácter benéfico y asistencial, que llegaron a presentar algunos problemas como se constata en el concilio de Montpellier (1214) ${ }^{6}$.

Se multiplicaron mucho las cofradías en los siglos XIII y XIV, de cuya confederación surgen las archicofradías o cofradías primarias, como la de la correa de san Agustín y santa Mónica en la Iglesia de Santiago de Bolonia el 14 de agosto de 1429 por el Papa Eugenio IV. A esta archicofradía se unió

3. Decreto Optatam totius n. 16. Cf. L. Hertling, Historia de la Iglesia (Barcelona 1969) 15-16; H. U. vON BALTHASAR, "Theologie und Spiritualität sind untrennbar", Osservatore Romano 28-VI-1984.

4. Patrología Latina (PL) $125,777-78$.

5. Concilio de Ruán, c. 45, J. B. MANSI, Sacrorum conciliorum nova é amplissima collectio, 22 (Graz 1961) 949.

6. Concilio de Montpellier, c. 45, J. B. MANSI, o.c., 22, col. 949-50. 
luego la de la Consolación por Gregorio XIII en $1576^{7}$. Se le unió también la de Nuestra Señora de Gracia, cuya devoción se había hecho popular en Lisboa desde 1362, Valencia del Cid desde antes de 1462, Perusia desde 1466, etc. Se le dio facultad al P. General mediante el breve Volentes del 12 de noviembre de 1579 para decretar en lo sucesivo la agregación de otras cofradías a la archicofradía de Roma, otorgando el correspondiente diploma de agregación ${ }^{8}$.

El rey Enrique IV de Castilla procuró restringir el número de cofradías, prohibiendo aquellas que no fueran para causas pías y con real licencia. Se suprimieron en 1473 las que habían sido fundadas desde 1464 sin licencia real. También las procuró controlar y restringir Carlos I en 1534 y 1552. Recientemente se han hecho estudios serios y valiosos sobre las cofradías en la Edad Media, tanto en España, como en Francia y otras naciones ${ }^{9}$.

Se las sometió a la visita de los obispos en el concilio tridentino. Las decisiones de Trento obligaban en España y sus colonias, por real cédula de Felipe II del 12 de julio de 1564. El control de los obispos se limitó a las visitas episcopales ${ }^{10}$.

7. G. M. Cavalieri, La sacra cintura (Milano 1737) 3-12. A la Cofradía de Nuestra Señora de la Consolación de Bolonia, que se convirtió pronto en Archicofradía, se van a unir incluso cofradías penitenciales, como la de Jesús Nazareno, Lignum crucis y Correa fundada en la iglesia de San Agustín de Bogotá, fundada el 4 de abril de 1599. Archivo Nacional de Colombia en Bogotá, Conventos, 48, ff. 929-943. La cofradía penitencial de Jesús Nazareno, existente ya en 1601 en la iglesia de San Agustín de Valladolid, se agregó en noviembre de 1616, junto con la de la "Cinta de San Agustín, Santa Mónica y San Nicolás de Tolentino". Cf. F. Arribas Arranz, La Cofradía de N. P. Jesús Nazareno de Valladolid (Valladolid 1946) 3-4. Esta cofradía logró tener su propia iglesia desde 1676.

8. F. CAMPO DEL POzo, La Virgen de la Consolación en Venezuela (Maracaibo 1958) 25; "Cofradías y doctrinas del convento de Mérida (Venezuela)", Archivo Agustiniano 71 (1987) 107 y 109, donde puede comprobarse cómo la Cofradía de Nuestra Señora de Gracia de Mérida se unió a la de la Consolación de Bolonia desde su fundación en 1599. Era también penitencial y estaba unida a la de Santa Cruz, procedente del convento de Gibraltar (Venezuela). La imagen del santo Cristo se conserva en la catedral de Maracaibo con una copia en la catedral de Sevilla. La agregación se hizo también con otras muchas asociaciones y cofradías existentes en iglesias de agustinos o regentadas por ellos. Algunas imágenes del santo Cristo eran copias del que se conserva en la catedral de Burgos, procedente del convento de San Agustín de esa ciudad.

9. Ley 3 y 5, tít. 14, lib. 8 de Recopilación de las Leyes destos Reynos 2 (Alcalá de Henares 1592) 185-86; Cf. F. J. GonZÁlez DíAZ, "Personalidad jurídica de las Hermandades y Cofradías en el nuevo Código de Derecho Canónico", Actas. Primer Congreso Nacional de Cofradías, 715 16.

10. Concilio de Trento, Sess. 22, De reformatione, cap. 8. J. Alberigo, Conciliorum Oecumenicorum Decreta (Bologna 1973) 740; F. A. LoREnZANA, Concilios Provinciales primero y segundo celebrados en la muy noble y muy leal ciudad de México 4 (México 1769) 7-8; Ley 6. tit. 2. lib. 1 de la Novisima recopilación 1 (Madrid 1805) 17-18. 
b) La intervención civil y canónica durante la Edad Moderna

Estamos preparándonos para la celebración del V Centenario del Descubrimiento y Evangelización de América, y conviene observar que las asociaciones cristianas jugaron un papel muy importante, pues algunas de estas cofradías eran catequéticas. Se está prestando actualmente mucha atención a la historia de las cofradías, que se tenía en parte olvidada ${ }^{11}$.

Se multiplicaron tanto las asociaciones que, al control eclesiástico, en España y sus colonias se unirá la autorización real o el control civil, como consta en distintas disposiciones reales. Algunas cofradías se fundaron para vivir mejor la Semana Santa, y así surgen no pocas, como las llamadas "penitenciales" en casi todas las ciudades y villas de España y América, como en otras naciones de Europa, especialmente en la parte católica de los Países Bajos, Alemania, Francia e Italia, que fomentaron el arte y la piedad con pinturas y tallas de Cristo en la Cruz y de la Virgen Dolorosa. A estas dos imágenes se añaden gestos dolorosos, como los de la espada y los cuchillos, con otros de alegría, como el encuentro gozoso de Cristo resucitado con María, cuyas imágenes acompañaban procesionalmente incidiendo profundamente en la vida de los cofrades ${ }^{12}$.

Las cofradías se multiplicaron durante los siglos XVI, XVII y XVIII en España y América. En la diócesis de Quito, fray Luis López de Solís, al celebrar el sínodo de 1594, impone la reducción de las mismas, ya que se multiplicaban entre los mismos aborígenes arbitrariamente. Algo semejante sucedía en las ciudades de Andalucía y en todas aquellas donde había grandes procesiones, como sucedió con Valladolid y Zamora. En las iglesias conventuales había también cofradías penitenciales, como la de Nuestra Señora de Gracia de Medina del Campo y otras, especialmente la de la Cruz y la Virgen Dolorosa. Disminuyen con Carlos III, y Carlos IV, que quisieron controlar sus reglas, en parte para reducirlas y beneficiarse de sus bienes, alegando la falta de aprobación rẹal. Sufrieron un rudo golpe durante el siglo XIX con la desamortización, que les impidió disponer de recursos económicos. No pocas subsistieron gracias al aporte de sus miembros ${ }^{13}$.

11. A. Linage Conde, "Cofradías de Sepúlveda", Imágenes de la fe, Número dedicado a las "Cofradías del Pueblo de Dios" 217 (1987) 5-17; E. VeracoichEA, "Lá Iglesia en la Venezuela Colonial", Boletín de la Academia Nacional de la Historia, Caracas, 70 (1987) 1 2.

12. L. SuÁrez Fernández: "La renovación religiosa del siglo XIV: La aparición de las cofradías", Actas. Primer Congreso nacional, 21-26; C. VICENT, Des charites bien ordennes, les confréries normandes de la fin du XII siècle au debut du XVI siècle (Paris 1988).

13. J. Villalva, "Los sínodos quitenses del Obispo Luis López de Solís: 1594 y 169", Sínodo de 1594, cap. 42 Instituto de Historia Eclesiástica, Quito nn. 3 y 4 (1988) 110-11; G. Moraleja, Historia de Medina del Campo (Medina del Campo 1971) 400; A. SanCHEZ 


\section{c) Las asociaciones y cofradías en el Código de 1917 con su reforma}

El tema de las asociaciones constituyó una novedad dentro de la legislación eclesiástica en el Código de 1917 con la tercera parte del libro II dedicada a los laicos, a los que se reconocen algunos derechos fundamentales (c. 682) como fieles cristianos. El título XVIII se titula "De las asociaciones de fieles en general" (cc. 684-699) llegando a promover no sólo las asociaciones religiosas sino también las culturales y benéficas, estableciendo en el c. 684 que los fieles "huirán de las asociaciones secretas, condenadas, sediciosas, sospechosas o que procuran sustraerse a la legítima vigilancia de la Iglesia". Tenían que ser erigidas, aprobadas o por lo menos recomendadas. No podían inscribirse en las que fuesen calificadas como condenadas, sospechosas, etc. ${ }^{14}$.

En el título XIX (cc. 700-725) se trata de las asociaciones en particular, definiéndolas como "entidades de fieles constituidas por la Iglesia, con nombre y naturaleza propia", que se clasificaban en tres instituciones: $1^{a}$ cofradías, que eran hermandades erigidas o aprobadas para el incremento del culto público, considerándose personas jurídicas públicas (cc. 685, 700, y 707 \& 2); $2^{\mathrm{a}}$ las Órdenes terceras, que tienden a promover la perfección en medio del mundo según las reglas para ello aprobadas por la Sede Apostólica (cc. 685,700 y $702 \& 1$ ); y $3^{\mathrm{a}}$ las pías uniones, que fueron creadas para ejercer alguna obra de piedad o caridad (cc. 685.700 y 707 \& 1). Los bienes de éstas últimas no eran eclesiásticos. Por estas normas se rigieron las asociaciones religiosas durante medio siglo ${ }^{15}$. Se aplicó en España el Concordato de 1953, que reconocía su personalidad jurídica, una vez que fuesen erigidas o aprobadas por la autoridad eclesiástica competente ${ }^{16}$.

El Concilio Vaticano II desarrolló el tema en varios documentos ${ }^{17}$, que recoge el Código de 1983, promoviendo gran estima por parte de los sacer-

DEL. BARRIo, Algunas notas sobre el tiempo de Pasión en Medina del Campo (Valladolid 1989) 20; E. MAtEO AviLÉs, "Ruina económica, desamortización y crisis procesional en las Cofradías malagueñas durante la primera mitad del siglo XIX", Actas. Primer Congreso Nacional de Cofradías, 381-90.

14. A. Alonso Lobo, "Asociaciones de fieles", Comentarios al Código de Derecho Canónico 2 (Madrid 1963) 9-22.

15. Ibid., 23-57. Cf. J. Creusen, "Associations pieuses", DDC 1 (París 1935) col. 1270-85; B. Olivares D'Angelo, "Asociación de fieles", Diccionario de Derecho Canónico (Madrid 1989) 60-61.

16. Concordato entre la Santa Sede y España, de 27 de agosto de 1953, art. 4, AAS 42 (1953) 627-28; Cf. J. L. DE Los Mozos, "La evolución del concepto de persona jurídica en el Derecho español", Quaderni fiorentini per la storia del pensiero giuridico moderno 11-12 (19821983) 833-58; "Legislación española sobre asociaciones", Asociaciones canónicas de fieles, $267-$ 71.

17. Apostolican actuositatem, nn. 18-25; Presbyterorum ordinis, $\mathrm{n} .8$ sobre asociaciones de sacerdotes; Gaudium et spes, nn. 52 y 68 sobre asociaciones familiares y de obreros, etc. 
dotes, religiosos y laicos hacia las asociaciones, que estaban decayendo por falta de orientación. La división de las asociaciones por razón del fin, como era el culto público, propio de las cofradías, no se mantiene durante el proceso codificador del nuevo Código, tomando como criterio de diferenciación su erección y su relación con la autoridad jerárquica. Se silencia el nombre de cofradías, que aparecía en el c. 707 \& 2 del Código de 1917 para atenerse a la nueva orientación. Uno de los promotores de las asociaciones privadas de fieles fue un miembro del Opus Dei, concretamente el benemérito profesor D. Pedro Lombardía, como él mismo lo manifestó públicamente, ya que de Instituto secular había pasado a ser una "pía asociación". No se pudieron quedar ni en "cofradía" para que sus bienes no fuesen eclesiásticos ${ }^{18}$. Esto suscitó lógicamente algunas observaciones y reservas. A primera vista y en la opinión de algunos canonistas, las cofradías tienen que seguir entre las asociaciones públicas, por razón del culto público ${ }^{19}$. Pero se da la circunstancia de que no pocas cofradías no tenían como fin el culto público que ya no es criterio o elemento diferenciador en el Código de $1823^{20 .}$.

\section{ASOCIACIONES DE LOS FIELES EN EL CÓDIGO DE 1983}

Se trata precisamente del desarrollo normativo y necesario del c. 215 , donde se establece el derecho de asociación de los fieles. Se pone este título

18. F. GonzÁlez Díaz, "Posición jurídica de las hermandades y cofradías en el Nuevo Código de Derecho Canónico" Asociaciones canónicas de fieles, 241-248, donde en la p. 242 se recoge una afirmación del profesor Pedro Lombardía pronunciada en la lección inaugural del Curso cofradiero de 1984-1985: "El planteamiento de recursos y reivindicaciones, dentro del. marco jurídico del Código, nunca puede suponer una rebeldía, sino una exigencia derivada del Concilio y del documento sobre los seglares". Algunos problemas del Opus Dei se solucionaron con la Prelatura personal. A veces surgen tensiones y diversas opiniones.

19. Entre los autores que defienden que las cofradías siguen siendo para promover el culto público está J. Manzanares, "Cofradías de Semana Santa en la actualidad. Ser y Misión", Actas. Primer Congreso Nacional, 161-88. Siguen esta opinión otros muchos autores, como Antonio Reyes y los que consideran a las cofradías a la luz del Código de 1917, ya que la palabra cofradía no aparece en el Código de 1983.

20. El erigir asociaciones de fieles o cofradías con el fin de promover el culto público corresponde a la autoridad eclesiástica competente o jerarquía según el c. 301 \& 1 . De aquí concluyen algunos autores, como A. DíAz DiAz, que el derecho de asociación de los fieles no se extiende a la creación de asociaciones públicas, El Derecho de asociación 195-98. No comparte esta opinión J. MANZanares, "Cofradías de Semana Santa", 169-69. Durante siglos surgieron muchas cofradías por libre iniciación de los fieles y se denominaban a veces hermandades. Cf. A. GARCÍA y Garcí, "El asociacionismo en la historia de la Iglesia y en el ordenamiento canónico", Asociaciones canónicas de fieles, 22-32. Sus miembros pueden optar actualmente por ser una asociación privada. El hecho de asistir a una procesión no equivale a fomentar o promover el culto público. Se puede hacer como algo privado a veces. Compartían esta opinión Pedro Lombardía, Lamberto de Echeverría y también Federico R. Aznar Gil. Ya en la redacción del c. 301 se sustituyó la expresión primitiva cultus publici ordinationem por cultum publicum promo- 
al final de la primera parte del pueblo de Dios, después de los clérigos, ya que éstos, como fieles, tienen también derecho de asociación al igual que los laicos. Se trata por eso también de las asociaciones de clérigos en el c. 302 y hay un capítulo dedicado a las asociaciones de laicos. La gran novedad la constituye el capítulo III "sobre las asociaciones privadas de fieles", que está llamando mucho la atención y está siendo objeto de no pocos comentarios. La Iglesia se actualiza en las asociaciones. En el esquema de 1980 se quiso poner a las asociaciones al lado de las sociedades e institutos religiosos, lo que se desechó en mayo de ese mismo año ${ }^{21}$.

a) Normas comunes a las asociaciones de fieles: sus clases, régimen, etc.

Se comienza por precisar que "existen en la Iglesia asociaciones distintas de los institutos de vida consagrada y de las sociedades de vida apostólica, en las que los fieles, clérigos o laicos, o clérigos junto con laicos, trabajando unidos, buscan fomentar una vida más perfecta, promover el culto público, o la doctrina cristiana, o realizar otras actividades de apostolado, a saber, iniciativas para la evangelización, el ejercicio de obras de piedad o de caridad y la animación con espíritu cristiano del orden temporal" (c. 298 \& 1). Se recomienda la inscripción en las que se hayan sido erigidas, aprobadas o recomendadas por la autoridad competente $(\& 2)^{22}$.

Por razón del fin, según el c. $298 \& 1$, pueden ser: $1^{\circ}$ para fomentar la vida más perfecta, $2^{\circ}$ para promover el culto público o la doctrina cristiana, $3^{\circ}$ para realizar obras de apostolado, como evangelización, obras de piedad o caridad y animación del orden temporal con espíritu cristiano.

Con relación a la jerarquía eclesiástica (nuevo criterio c. 298 \& 2): unas pueden ser erigidas por la autoridad competente en forma pública, otras alabadas o recomendadas. Se habla luego de asociaciones privadas en lo cc. 299 y 301, que pueden obtener personalidad jurídica mediante decreto (c. $322 \& 1$ ). Es decir, que hay asociaciones privadas aprobadas y erigidas ${ }^{23}$.

Por relación a sus miembros: pueden ser comunes a todos los fieles, mientras no conste otra cosa; clericales, si reúnen los requisitos del c. 302; lai-

21. P. G. MarcuzzI, "Le associazzioni dei fedeli nel nuovo Codice di Diritto Canonico", Apollinaris 5691986 (545-64).

22. L. MARTinez Sistach, "Asociaciones públicas y privadas de laicos", Jus Canonicum 26 (1986) 151-52.

23. J. Ferrer Ortiz y Ti Rincón, "Asociaciones de fieles públicas y privadas", Manual de Derecho Canónico (Pamplona 1988) 221-25. 
cales, si son sólo de laicos (cc. 327-329) y mixtas, como las Órdenes terceras de las que se trata en el c. $303^{24}$.

Todas deben tener sus estatutos (c. 304), donde se determine el fin $u$ objetivo social de la asociación, su sede, el gobierno y las condiciones que se requieren para entrar en ellas, modo de actuar etc. Ninguna asociación puede llamarse "católica", según el c. 300 , sin el consentimiento de la autoridad competente, conforme a la norma del c. 312. Las cofradías, según el Código de 1917, eran asociaciones públicas, por tener entre sus fines el culto público. Actuaban en nombre de la Iglesia (c. 116 \& 1). Actualmente algunas cofradías pueden ser asociaciones privadas.

Son asociaciones las archicofradías y pías uniones, aunque nada se dice de ellas. Hay que aplicarlas estas normas. Su régimen depende de los estatutos (c. 304), que deben tener todas las asociaciones tanto públicas çomo privadas, cualquiera que sea su nombre. Se rigen también por sus normas internas (c. 309). Las archicofradías eran personas públicas, mientras que las pías uniones no lo eran, y sus bienes no eran, ni son eclesiásticos ${ }^{25}$.

Sobre todas hay cierta vigilancia (c. 305) y coordinación (c. 311) que es mayor en las públicas. En cuanto a la admisión de los socios hay que atenerse a los estatutos propios (c. 307), lo mismo en lo referente a la expulsión (c. 308) y causa justa. Pueden tener sus privilegios (c. 306) de acuerdo con el Derecho y los estatutos. Tienen más las Ordenes terceras.

Terminan las normas comunes con la novedosa recomendación dirigida a los miembros de institutos religiosos, que dirigen asociaciones de apostolado en coordinación con las demás bajo la dirección del Ordinario del lugar (c. 311). Se insiste en su vinculación a la Iglesia.

b) Asociaciones públicas de los fieles (cc. 312-320)

Las asociaciones públicas son siempre persona jurídica, que puede actuar de acuerdo con el c. 116 en nombre de la Iglesia, por lo que necesita siempre de la correspondiente erección por la autoridad competente. Si se trata de asociaciones universales, por la Santa Sede (c. 312 \& 1,1). Hay que tener en cuenta las normas especiales sobre esta materia, como el Directorio del año $1971^{26}$. Si se trata de asociaciones nacionales, por la Conferencia

24. A. Alonso Lobo, "Asociaciones de fieles", 30-35, donde puede verse las Ordenes y Congregaciones religiosas que tienen Ordenes terceras.

25. Ibid., 35-41.

26. Directorium, "Respiciens normas quibus Instituta Internationalia Catholica definuntur", 3-XII-1971 AAS 63 (1971) 948-56; Apostolatus peragendi 10-XII-1976, n. 6, AAS 68 (1976) 696700 . 
Episcopal, que las controla a través de una comisión. Luego veremos las normas de la Conferencia Episcopal Española sobre esto.

Si la asociación es diocesana, se erige o aprueba por el obispo diocesano; pero no por el administrador. Tienen un tratamiento especial las que dependen de las Ordenes religiosas, congregaciones o institutos de vida consagrada. Pero aun en estos casos se requiere el consentimiento del obispo diocesano, dado por escrito; pues el que se ha dado para fundar una casa religiosa, vale para erigir en la misma o iglesia aneja, una asociación, que sea propia de ese instituto (c. $312 \&$ 2).

Se puede constituir también una federación de asociaciones públicas, como persona jurídica pública (c. 313). Los estatutos de toda asociación pública, así como la revisión o cambio, necesitan de aprobación de la autoridad eclesiástica competente conforme a la norma del c. $312 \& 1$ (c. 314 ). Actúan bajo la vigilancia de la autoridad eclesiástica (c. 315) que confirma o ratifica algunos cargos, como el de presidente (c. 317). No pueden ser presidentes quienes desempeñan cargos de dirección de partidos políticos (c. 317 \& 4). Hay posibilidad de nombrar un comisario, cuando lo exijan causas graves; remover del cargo al presidente con justa causa con la particularidad de que sea oído por el que lo nombró o confirmó; y puede remover al capellán conforme a los cc. 192-195 aquel que lo nombró (c. 318 \& 1-2). La administración de los bienes debe hacerse bajo el control de la autoridad eclesiástica ya que sus bienes son eclesiásticos (cc. 319 y 1357 \& 1) con rendición anual de cuentas ${ }^{27}$. La supresión se hace por la autoridad competente que la erigió de acuerdo con el c. 320 por causas graves.

c) Asociación privada de fieles (cc. 321-326)

Es una de las grandes novedades del Código de 1983. Ha sido uno de sus promotores, como se dijo antes, el profesor Pedro Lombardía, quien manifestó "que se trata de un gran logro, aunque la técnica es aún defectuosa". La línea es clara y hay que llevarla a sus últimas consecuencias ${ }^{28}$.

Las asociaciones privadas responden a un derecho de los fieles, que las dirigen y administran de acuerdo con las prescripciones de los estatutos

27. El Coetus que elaboró las normas sobre la vigilancia del 17 al 23 de julio de 1979, se cuestionó el problema de los bienes de las asociaciones privadas. Se estableció que sus bienes no eran eclesiásticos y que se administraban según sus estatutos propios bajo la vigilancia de la Iglesia sobre su destino y fines. Cf. Communicationes 12 (1989) 391-99.

28. P. Lombardia "Autonomía privada en la Iglesia", Ecclesia 44 (1984) 413-14; L. EcHEVERrIA, "Las entidades privadas en el nuevo Código", Ecclesia 43 (1983) 1458-59, donde las consideraba como una novedad. 
c. 321). Según el esquema de 1977 (c. 73 \& 2) se podían constituir a iure con personalidad jurídica ${ }^{29}$.

Hay asociaciones privadas sin personalidad jurídica. Están constituidas por sus miembros, que las dirigen y administran libremente (c. $324 \& 1$ ); sus bienes no son eclesiásticos y están bajo una vigilancia general de la autoridad eclesiástica (c. 323). Se pueden suprimir según los estatutos o por la autoridad competente. No pueden ser sujeto de derechos y obligaciones, como asociación, por lo que necesitan de un mandatario (c. 310). Éstas pueden ser alabadas, recomendadas o reconocidas por la autoridad eclesiástica que "revisa" (recognoscantur) sus estatutos (c. 299 \& 2-3).

Para que tenga personalidad jurídica la asociación privada se requiere que sea constituida por decreto formal de la autoridad competente indicada en el c. 312 \& 1 y que sus estatutos hayan sido aprobados (c. 322 \& 2). Los cargos son de libre elección, con mayor autonomía y libertad en su administración privada, porque sus bienes no son eclesiásticos. Se suprimen según los estatutos y por la autoridad competente (c. 326 \& 1) "si su actividad es un daño grave de la doctrina o disciplina eclesiástica, o causa escándalo a los fieles".

Los estatutos son necesarios: deben tener aprobación en las alabadas y recomendadas (322 \& 2). La vigilancia de la autoridad eclesiástica es vaga y general para ver si se emplean los bienes según los fines de la asociación (c. $325 \& 1$ ) y sobre los bienes que hayan recibido por donación o legado (c. 325 \& 2) para ver si se cumple la voluntad de los donantes. La fundación no autónoma no puede adscribirse a una asociación privada, sino a una asociación con personalidad pública (cc. 1203-1204) ${ }^{30}$.

Si desean un consejero espiritual, pueden elegirlo libremente entre los sacerdotes y no tiene en manera alguna carácter representativo del Ordinario del lugar, que puede negarse a confirmarlo para el cargo (c. 324 \& 2).

d) Normas especiales sobre asociaciones de laicos y su reconocimiento

En los cc. 327-329 se trata de las asociaciones tanto públicas, como privadas, sólo de laicos. Ofrecen poco interés al tratarse de exhortaciones y recomendaciones. Se insiste en su alabanza para fines espirituales y animar

29. P. A. BonNET, "De Christifidelium consociationem lineamenta, juxta Schema, De Populo Dei, Codicis recogniti anni 1979, adumbratione", Periodica 71 (1982) 267-82, donde hace ver la distinción entre las asociaciones privadas y las públicas con sus aspectos positivos y negativos.

30. L. DE EcheVERría, "Fundaciones piadosas", El Derecho patrimonial canónico en Espa$\tilde{n} a$ (Salamanca 1985) 99-124. 
el orden temporal con una unión entre la fe y la vida (c. 327). Se recomienda la colaboración con otras asociaciones (c. 328) y que sus miembros procuren adquirir la formación necesaria para el apostolado propio de los laicos (c. 329). El reconocimiento por parte de la autoridad eclesiástica puede ser mediante alabanza, recomendación o la erección ${ }^{31}$.

El control de la jerarquía es muy importante, pues el hecho de estar reconocidas o erigidas por la autoridad competente, puede darles en algunos casos facilidades para ser reconocidas por la ley civil, cosa importante para adquirir el carácter de persona jurídica ante el Estado y cumplir mejor con su finalidad.

Se ha presentado a veces el caso de asociaciones, que se han arrogado la calificación de católicas para congraciarse con la jerarquía o con fines peculiares, incluso de interés privado, como sucedió con el Concordato de 1953, en virtud del art. 4. Algún obispo aprobó alguna asociación, como católica, porque le había dado una buena limosna y decía dedicarse a importar objetos religiosos y luego tenía un comercio clandestino y hasta de contrabando. Éste y otros casos motivaron un mayor control con el Registro de las asociaciones ante el Ministro de la Gobernación primero y luego ante el de Justicia por Decreto del 12 de mayo de $1959^{32}$. Ya en el Decreto Apostolican Actuositaten, n. 24, se establece que "ninguna obra debe arrogarse el nombre de católica sin el consentimiento de la legítima autoridad eclesiástica". Se han dado normas especiales posteriormente sobre esto por el Código de 1983 (c. 300) y Conferencias Episcopales.

El Acuerdo jurídico de 1979, después de especificar el reconocimiento de las Órdenes y congregaciones religiosas, sus provincias y sus casas en el art. I, n. 3, añade: 1) "Las asociaciones y otras entidades y fundaciones religiosas, que estando erigidas canónicamente en la fecha de entrada en vigor del presente Acuerdo, no gocen de personalidad jurídica civil y las que se erijan canónicamente en el futuro por la competente autoridad eclesiástica, podrán adquirir la personalidad jurídica civil, con sujeción a lo dispuesto en el ordenamiento del Estado, mediante la inscripción en el correspondiente Registro en virtud de documento auténtico en el que consten la erección, fines, datos de identificación, órganos representativos, régimen de funciona-

31. H. SCHEWENDENWEIN, Das neue Kirchenrecht (Graz 1984) 167.

32. Éste y otros decretos sobre asociaciones, como el del 25 de enero de 1941, se actualizaron en la Ley reguladora de asociaciones del 24 de diciembre de 1964, que además del registro correspondiente, exigía presentación de estatutos con determinación de fines lícitos y modo de proceder. Cf. ARANZADi, Leyes civiles sustantivas (Pamplona 1973) 1147-54. Ver también "Personalidad civil de los entes eclesiásticos" y "Actividades benéficas y asistenciales de la Iglesia", Los Acuerdos entre la Iglesia y España (Madrid 1980) 221-90. 
miento y facultades de dichos órganos". (El documento auténtico se pasa por el Registro) ${ }^{33}$.

En las Disposiciones transitorias se especifica la importancia del Registro: 1) "Las órdenes, congregaciones y otros institutos de vida consagrada, sus provincias y sus casas, y sus asociaciones y otras entidades o fundaciones religiosas, que tienen reconocida por el Estado la personalidad jurídica y la plena capacidad de obrar, deberán inscribirse en el correspondiente Registro del Estado en el más breve plazo posible. Transcurridos tres años desde la entrada en vigor en España del presente Acuerdo, sólo podrá justificarse su personalidad jurídica mediante certificación de tal Registro, sin perjuicio de que pueda practicarse la inscripción en cualquier momento" ${ }^{34}$. Es importante y necesario a veces el reconocimiento eclesiástico para lograr el carácter de autenticidad y luego obtener el Registro. En el documento, que se pasa por la curia diocesana $u$ organismo correspondiente debe constar: $1^{\circ}$ la declaración de la erección o reconocimiento explícito; $2^{\circ}$ los fines de la institución; $3^{\circ}$ los datos de identificación, que en principio parece limitarse al nombre; $4^{\circ}$ los órganos representativos, régimen de funcionamiento y facultades de funcionamiento y facultades de los mismos, según los estatutos propios. En la ley de libertad religiosa se precisa mejor esto en España a partir del 5 de julio de $1980{ }^{35}$ y el Real Decreto 142/1981, del 9 de enero de 1981, que crea el Registro de Entidades Religiosas, ubicado en el Ministerio de Justicia y dependiente de la Dirección General de Asuntos Religiosos. Según este Real Decreto, art. 2, "En el Registro de Entidades Religiosas se inscribirán: ...C) Las Entidades asociativas religiosas constituidas como tales en el ordenamiento de las Iglesias y Confesiones". Luego, en el art. 3, se precisa cómo ha de hacerse la inscripción y requisitos: $1^{\circ}$ "La inscripción se practicará a petición de la respectiva entidad, mediante escrito al que acompañe el testimonio literal del documento de creación debidamente autenticado o el correspondiente documento notarial de fundación o establecimiento en España". $2^{\circ}$ "Son datos requeridos para la inscripción: a) documentación de la Entidad, de tal modo que sea idónea para distinguirla de cualquier otra; b) domicilio; c) fines religiosos con respecto de los límites establecidos en el artículo $2^{\circ}$ de la Ley Orgánica 7/1980 de 5 de julio, de Libertad Religiosa, al ejercicio de los derechos dimanantes de la libertad religiosa".

"En el caso de las Entidades asociativas religiosas, a que hace referencia el apartado c) del artículo anterior, el cumplimiento de este requisito deberá

33. A. ReINA BeRnÁldeZ, Legislación eclesiástica (Madrid 1984) 108.

34. Ibid., 111.

35. Ibid., 131-35. 
acreditarse mediante la oportuna certificación del Órgano Superior en España de las respectivas Iglesias o confesiones. d) Régimen de funcionamiento y Organismos representativos, con expresión de sus facultades y de los requisitos para la válida designación. e) Potestativamente, la relación nominal de las personas que ostentan la representación de la Entidad. La correspondiente certificación registral será prueba suficiente para acreditar esta cualidad" 36 .

Hay una Resolución del 11 de marzo de 1982 de la Dirección General de Asuntos Religiosos del Ministerio de Justicia, que clarifica lo referente a entidades o asociaciones religiosas dependientes de la Iglesia Católica, como sucede con la certificación o prueba documental, anteriormente citada del apartado e), n. 2 del art. 3 del Real Decreto de 9 de enero de 1981, "para acreditar los fines religiosos de las Entidades Asociativas peticionarias de la inscripción deberá ser expedida o visada por el órgano competente de la Conferencia Episcopal". Esto debería ser sólo para entidades de ámbito nacional; pero parece comprender también a las diocesanas. Se añade en el art. $4^{\circ}$ de la Résolución: "Las firmas del documento en que conste, a los efectos de inscripción en el Registro, la erección, fines, datos de identificación, órganos representativos, régimen de funcionamiento y facultades de dichos órganos, deberán ser legitimadas por Notario Civil". Esto debe ser tenido en cuenta ${ }^{37}$.

Cabría la posibilidad de lograr la personalidad de carácter civil con fines religiosos o una doble personalidad, lo cual no ve bien la Conferencia Episcopal Española, a no ser en situaciones excepcionales. Ella misma reconoce que "a veces la propia autoridad jerárquica ha sugerido ese cauce, cuando determinadas circunstancias hacían que la Iglesia pudiera cumplir mejor sus fines a través de estas asociaciones civiles que si lo hiciera a través de asociaciones canónicas". "Instrucción sobre asociaciones canónicas de ámbito nacional", n. 35, aprobada el 24 de abril de $1986{ }^{38}$. Hay otros medios también para probar de hecho la existencia de la personalidad jurídica.

Hay casos de asociaciones sin personalidad jurídica. Se dan de facto al margen del Derecho canónico y civil, al no haber formalizado su constitu-

36. Ibid., 136-37.

37. M. E. Olmos OrTEGA, "El registro de entidades religiosas", Revista Española de Derecho Canónico 45 (1988) 97-121. En caso de negativa de inscripción civil, cabe recurso administrativo ante la Audiencia Nacional según resulta de aplicar el art. 66 de la Ley 6/1985, del 1 de Julio Ley Orgánica del Poder Judicial y art. 63 de Ley 1/1977, del 4 de enero. Cf. M. LOPEZ AlARCÓN, "Personalidad jurídica civil como "asociaciones culturales".

38. Boletín de la Conferencia Episcopal Española (CEE 3 (1986) 83-84. De hecho en algunas diócesis, varias cofradías han logrado la personalidad jurídica civil como "asociaciones culturales". 
ción por las razones que sea. Al tratarse de un grupo que no tiene una finalidad lucrativa, como sucede de ordinario con las religiosas, aunque no se cumplan los requisitos de la Ley del 24 de diciembre de 1964, ni los exigidos por el régimen vigente, que resulta del art. 22 de la Constitución de 1978, pueden tener sus derechos adquiridos, lo mismo que puede haber también responsabilidad frente a terceros de buena fe $^{39}$.

\section{ALGUNAS NORMAS Y OBSERVACIONES COMPLEMENTARIAS}

Nos encontramos con una realidad compleja de muchas cofradías de Semana Santa, además de otras asociaciones que necesitan actualizarse o ponerse al día según los nuevos criterios del Derecho Canónico, ya que las antiguas cofradías solían estar erigidas, eran asociaciones públicas según el Código de 1917, y respondían a determinadas expresiones del fenómeno religioso para incrementar el culto público y una mayor vivencia de la fe de acuerdo con sus Estatutos en tiempos pasados y presentes.

Hay que agradecer a los miembros de las cofradías de Semana Santa sus aportes a las procesiones y culto público con una riqueza espiritual, que ha tenido repercusión local, nacional e internacional. Han sabido conservar imágenes, templos y tradiciones, que reflejan la auténtica conciencia del pueblo cristiano, y han sabido reencontrarse año tras año con sus imágenes para revivir mejor el drama de la Pasión. No hay que olvidar que ya a mediados del siglo XVI funcionaban las cofradías de la Santa Cruz, la de Nuestra Señora de la Pasión, las Angustias, la Piedad y otras en casi todas las ciudades, villas y pueblos de España.

\section{a) Posibilidad de un Directorio con un Estatuto marco}

La Conferencia Episcopal Española ha dado una "Instrucción sobre las asociaciones canónicas de ámbito nacional" con unas normas muy bien elaboradas, donde se dice en el último número "no se descarta que puedan tener aplicación en asociaciones diocesanas, si el Obispo lo estima oportuno, supuestas las necesarias adaptaciones" ${ }^{40}$.

Algunas diócesis tienen ya "Directorios", como las de Sevilla y Barcelona, sirviendo de orientación a otras diócesis. El Estatuto marco de Barcelona

39. J. L. DE LOS MOZOS, "Legislación española sobre asociaciones", Asociaciones canónicas, 267-98, donde se mencionan dos sentencias reconociendo la personalidad y los derechos adquiridos sin haber registro.

40. Boletín de la CEE 3 (1986) 84. 
es para las asociaciones públicas ${ }^{41}$, por las que se inclina L. Martínez Sistach; pero el Código de 1983 da opción a la posibilidad de "la asociación privada" por la que pueden optar libremente los miembros de las cofradías y asociaciones respetando tres principios también fundamentales que aparecen en el concilio Vaticano II y los recogen el mismo Código y la Instrucción de la Conferencia Episcopal Española n. 5 con otras notas complementarias; $1^{\circ}$ "su clara adhesión a la fe católica y al magisterio de la Iglesia que la interpreta y la proclama, su empeño en realizar una íntima unidad entre fe y vida [c. 327]; $2^{\circ}$ su comunión con el Obispo en cuanto principio y fundamento de unidad en su Iglesia particular, y $3^{\circ}$ la disponibilidad a colaborar con las demás asociaciones públicas; lo mismo se diga de las asociaciones privadas nacidas en virtud del pluralismo asociativo que la Iglesia reconoce y fomenta" ${ }^{42}$. Se precisa también lo que significa actuar en nombre de la Iglesia con mayor vinculación en las públicas (n. 12). El Estatuto marco de Barcelona y las normas de la CEE son recogidos por Antonio Reyes, que es partidario de que las cofradías sean persona jurídica pública, tal como lo venía defendiendo la doctrina y el Código de 1917 que no derogaba la legislación anterior, como de hecho lo hace el Código de 1983 en el c. 6 \& 1, $1^{\circ}$, donde expresamente se declara abrogado el Código de 1917, según se ha observado anteriormente.

El Estatuto marco debe respetar las diversas posibilidades que ofrece el Código de Derecho Canónico, aunque se pueden dar normas complementarias a nivel diocesano de acuerdo con el principio de subsidiariedad, es decir, subordinadas a las normas disciplinares de rango universal y nacional. Las mismas asociaciones de carácter nacional, al establecerse en la diócesis, "se requiere el consentimiento del Obispo diocesano dado por escrito, aun en el caso de que esa erección se haga por privilegio apostólico; sin embargo, el cosentimiento escrito del Obispo diocesano para erigir una casa de un instituto religioso vale también para erigir, en la misma casa o en la iglesia aneja, una asociación que sea propia de ese instituto" (c. 312 \& 2).

Suelen tener su Estatuto marco, al menos como dirección, las cofradías de los distintos institutos religiosos con un margen discrecional para adaptar-

41. L. MARtínez Sistach, "Estatuto marco de una asociación pública de fieles en la Iglesia", Las Asociaciones de Fieles (Barcelona 1986) 131-39. Además del Estatuto marco de Andalucía recomendado en una carta colectiva de los Obispos andaluces en 1988, hay Estatuto marco en las diócesis de Astorga, León, Valladolid, etc.

42. Boletín de la CEE 3 (1986) 80.

43. Dentro de la Orden de San Agustín, la Pía Unión de Santa Rita o Talleres de Caridad de Santa Rita han tenido un "Reglamento" compuesto por el P. Salvador Font y aprobado por el Obispo de Madrid Alcalá el 30 de enero de 1902. Se complementaba con los Estatutos de la Cofradía de Santa Rita de Casia y Santa Clara de Montefalco. Se obtuvo aprobación del Papa Pío X el 8 de noviembre de 1907. Puede verse en la obra del P. Lucas Garía, Manual del Cofrade 
se a las circunstancias de cada lugar. Estas asociaciones, serán públicas o privadas según el deseo de los fieles miembros ${ }^{43}$.

\section{b) Normas especiales de la conferencia Episcopal Española}

La Conferencia Episcopal Española en "Introducción sobre las Asociaciones canónicas de ámbito nacional", que ya hemos mencionado anteriormente al tratar del Directorio con un Estatuto marco, se dan algunas normas generales, donde se dice en el n. 12 sobre las asociaciones públicas, lo siguiente: "Las asociaciones públicas, más estrechamente vinculadas al ministerio jerárquico y a través suyo a toda la comunidad cristiana, tienen como nota peculiar su necesaria constitución en persona jurídica pública y el cumplir en nombre de la Iglesia, a tenor de las prescripciones del derecho, la misión que se les confía, mirando al bien público (cf. c. 313 y 116 \& 1). Adviértase, sin embargo, que obrar en nombre de la Iglesia no significa obrar en nombre de la autoridad de Iglesia, pero sí una vinculación con la Jerarquía mayor de la que puede darse en las asociaciones privadas. Recibir misión en la medida en que la asociación la necesite (cf. c. 313), ni priva a los fieles de su necesaria facultad de obrar por propia iniciativa, ni les autoriza a cualquier tipo de actuaciones, sino a las congruentes con sus fines dentro del derecho común estatutario".

"13. En la elaboración de estatutos no debe faltar ninguno de los datos enumerados, requeridos por el derecho; pero no es necesario, ni conveniente que se descienda a detalles propios de otro tipo de documentos, como son los reglamentos de régimen interno, que la asociación puede darse legítimamente (cf. c. 309), y que, de estar en los estatutos, podrían entorpecer la deseable agilidad y aún rapidez en los trámites que deba observar la autoridad eclesiástica competente" ${ }^{44}$. Aquí se comprueba cómo es voluntad del Código y de la Conferencia Episcopal Española, dejar a los miembros amplia libertad de autonomía en el modo de proceder interno y en la elaboración de su reglamento.

Las formalidades de admisión y de expulsión se han de precisar en los estatutos, donde se podrán añadir algunos requisitos especiales. Se requiere cierta idoneidad para ser miembro, como observa la CEE en el n. 15. "Los miembros de estas asociaciones han de ser necesariamente católicos, que no se encuentren incursos en una excomunión impuesta o declarada. Y quienes,

de Santa Rita (Zaragoza 1944) 127-41. La Pía Unión de Santa Rita y sus Talleres estaban afiliados a la Archicofradía de la Consolación de Bolonia y sus bienes no eran eclesiásticos. La Pía Unión de Santa Rita subsiste aún en muchas iglesias de los agustinos y en otras atendidas por clérigos seculares. Sucede algo semejante con la asociación de Madres Cristianas.

44. Boletín de la CEE (1988) 81. 
estando legítimamente adscritos, se apartaran de la comunión eclesial o incurrieran en la excomunión antes indicada, deberán ser expulsados de la asociación, después de haber sido previamente amonestados, de acuerdo con los propios estatutos (cf. c. 316 \& 1-2)" ${ }^{45}$.

Los estatutos deben determinar la forma de designación y la duración en el cargo de su presidente, que debe ser confirmado si la asociación es de ámbito nacional, por la $\mathrm{CEE}$, que lo hará a través de su Comisión permanente (n. 16). Si es diocesana, por la autoridad eclesiástica competente, que confirma al elegido o instituye al presentado. La misma autoridad eclesiástica nombra capellán o asistente eclesiástico, después de oír, cuando sea conveniente, a los oficiales mayores de la asociación (c. 317 \& 1). Puede existir derecho de presentación. Si es religioso el capellán, hay que oír al superior mayor respectivo, que lo nombra o confirma si la asociación pertenece a su instituto religioso.

Al exponer estas normas a los cofrades y miembros de asociaciones, muchos optan por la asociación privada con personalidad jurídica, dada su mayor autonomía, como sucedió en un encuentro regional de cofradías penitenciales celebrado en Villagarcía (Valladolid) los días 16, 17 y 18 de septiembre de 1988. Esto aumentó la tensión existente en algunas cofradías penitenciales de Valladolid, que tenían incluso iglesias con culto y deseaban acogerse al régimen de asociaciones privadas.

Se hizo una consulta a la Junta de Asuntos Jurídicos de la Conferencia Episcopal Española sobre "el carácter público o privado de las cofradías erigidas para el incremento del culto público, a tenor del Código del Derecho Canónico vigente". Con fecha 21 de diciembre de 1988 se contestó que tenían carácter público ${ }^{46}$. Dada la formulación de la pregunta "para incremento del culto público", la respuesta lógicamente es correcta, máxime si se

45. Ibid., 81 .

46. CEE, Junta de Asuntos Jurídicos, Dictamen sobre el carácter público o privado de las cofradías erigidas para el incremento del culto público a tenor del Código de Derecho vigente, Madrid 21 de diciembre de 1988, 7 ff. No se ha contestado directamente a la cuestión presentada por algunas cofradías de Valladolid, anteriores al Código de 1917, que han solicitado aprobación de sus estatutos, donde se consideran asociaciones privadas de acuerdo con el Código de 1983. El no permitirlo en algunos casos sería cercenar un poco el derecho de autodeterminación. En Valladolid se ha establecido en el Directorio de cofradías de Semana Santa del 18 de enero de 1991, art. 1, que "las asociaciones de fieles, conocidas con el nombre de cofradías de Semana Santa, representan hoy en nuestra diócesis un vivo testimonio de piedad y culto público", etc. Se considera a las dieciocho cofradías penitenciales como públicas, alegando que su fin es fomentar o incrementar el culto público. Esto debe ser tenido en cuenta al renovar los Estatutos para su preceptiva aprobación. Se establece algo parecido en Las Hermandades y Cofradías. Carta Pastoral de los Obispos del Sur de España (Madrid 1988) 21, donde se dice que "los cofrades, junto con el fin peculiar del culto público, deben asumir las responsabilidades propias de la Iglesia". 
argumenta con la doctrina del Código de 1917, teniendo también en cuenta el Código de 1983 en lo referente al culto público, que solía ser un fin de las cofradías (cc. 298 \& 1 y 301).

En la misma respuesta se reconoce expresamente que "nada impide que puedan mantener su nombre tradicional de cofradías $(o)$ hermandades, alentadas por el propio legislador, cf. c. $304 \& 2 "{ }^{47}$. Esto quiere decir que puede haber cofradías con personalidad jurídica privada.

Como observa la misma Conferencia Episcopal Española en el n. 7 b) de su "Instrucción" hay asociaciones que necesariamente tienen que ser públicas por ser sus fines asociativos de carácter público, "como transmitir la doctrina cristiana, promover el culto público, o perseguir finalidades reservadas por su propia naturaleza a la autoridad eclesiástica (cf. c. 301), los cuales sitúan a la asociación que los persigue entre las llamadas asociaciones públicas, con las consecuencias que luego se indican" ${ }^{48}$.

"Pueden también dar lugar a asociaciones públicas aquellas que persigan otros fines espirituales, cuando a juicio de la autoridad eclesiástica competente, no se provea suficientemente a su obtención con la mera iniciativa privada" (ibid., n. 8). Esta decisión corresponde a la Conferencia Episcopal a nivel nacional y al obispo a nivel diocesano.

En la misma "Instrucción", n. 9, punto tercero, se observa que "si se trata de una asociación privada, no se implantará en la diócesis sin previa notificación al Obispo diocesano como requisito para que éste pueda cumplir las normas explícitas relativas a su gobierno pastoral sobre todo tipo de asociaciones (cf. cc. $264 \& 1 ; 305 ; 323 ; 394$ y 1264) y así constará en los estatutos" . 9 . El Obispo diocesano puede poner limitaciones y control según estos cánones, respetando una mayor autonomía de gestión en las de carácter privado, que en algunos casós necesariamente tendrá que ser erigida en persona jurídica, aunque siga siendo privada, para poder ser sujeto de obligaciones y derechos, sin tener que actuar por un mandatario, ni contraer obligaciones conjuntamente "y adquirir y poseer bienes, como condueños y

47. Ibid., n. 3. Al dar los presupuestos según el nuevo Código, se reconoce que "no figura el término cofradía... Figuran, no obstante implícitamente al mencionar los fines que las caracterizan: promover el culto público (c. 298 \& 1, donde expresamente se cita esos mismos cánones, reconociendo a los fieles la facultad para constituir asociaciones mediante acuerdo privado, añadiendo \& 2 que "esas asociaciones se llaman privadas". Algunos miembros del Coetus dieron su opinión sobre la naturaleza de los bienes de las asociaciones privadas, que no son eclesiásticos, y su vigilancia, como hemos visto en la nota 27 . En el caso de que una cofradía tenga como fin promover el culto público o enseñar la doctrina cristiana en nombre de la Iglesia, tiene que ser persona jurídica pública, lo mismo sucede con las confederaciones (c. 313).

48. Boletín de la CEE 3 (1986) 80.

49. Ibid., 80 . 
cooposesores". Esto se exige en la "Instrucción" y también en el c. 310. En el n. 30 se reconoce que en las asociaciones privadas "no se puede imponer la rendición anual de cuentas" cf. c. $1287 \& 1$, aunque se puede exigir, habiendo motivos, "rendición de cuentas, como tutela del fin de la asociación y del bien común eclesial. El Código especifica el control en caso de donación o legado para causas pías (c. $325 \& 2)^{50}$.

Al hablar de la vigilancia en el c. 305 entre las normas generales para las asociaciones, se hace una omisión respecto a la Conferencia Episcopal. Esto está creando algunas dudas, que se irán resolviendo poco a poco con posibles respuestas de la Comisión Pontificia ${ }^{51}$.

\section{c) Normas especiales de las Constituciones de la Orden de San Agustín}

En la Orden de San Agustín se ha recomendado mucha atención a las asociaciones especialmente a las agustinianas, como se hace en las Constituciones promulgadas en 1979, hasta el punto de que en el n. 44 se las considera como parte de la Familia Agustiniana, mencionando expresamente a las "fraternidades seculares y sociedades erigidas bajo el título y magisterio de San Agustín. A la Familia Agustiniana pertenecen también en cierto modo los afiliados a la Orden" ${ }^{52}$.

En las Constituciones se precisa lo que son las fraternidades seculares, las sociedades de San Agustín y la afiliación a la Orden (nn. 48-50) con su espiritualidad y se establece en el n. 170 lo siguiente:

"Atiéndase de modo especial a las sociedades y fraternidades seculares vinculadas a nosotros (a la Orden) para que sus miembros cultiven una vida cristiana más intensa y puedan ejercer dentro de la sociedad humana su actividad apostólica" 53 .

Después de tratar de cómo ha de funcionar una parroquia (n. 173) y cómo se ha de realizar la evangelización con especial atención a los más débiles, pobres y necesitados (n. 174) se establece en el n. 175:

"De acuerdo con la mente de la Iglesia foméntese cuanto sea posible la cooperación de los laicos utilizando su trabajo y cualidades, y promoviendo sus asociaciones de actividad apostólica según lo aconsejen las características de cada país" ${ }^{54}$.

50. 49: Ibid., 83

51. L. M. SistACH, "Asociaciones públicas de laicos", 168-69. Se eliminó lo referente a la vigilancia por parte de la Conferencia Episcopal, que figuraba en el Esquema enviado a consulta del episcopado, c. 44, ante las enmiendas recibidas. Communicationes 12 (1980) 98.

52. Regla y Constituciones de la Orden de San Agustín. (Madrid 1979) 54.

53. 49. Ibid., 106. Sigue igual en la edición última (Roma 1990).

54. 49. Ibid., 107. 
Lamentablemente con la puesta en práctica del Vaticano II y el Código de 1983, no se ha prestado la debida atención a las fraternidades agustinianas, tercera Orden y otras asociaciones, como la Pía Unión de Santa Rita. Se les ha procurado atender, sin hacer promoción en algunas iglesias y parroquias agustinianas de las cofradías existentes, ni fomentarlas según se exige en las Constituciones, que les hacen partícipes de la espiritualidad de Orden de san Agustín, haciendo una especial mención en el n. 48 de las fraternidades seculares, como la de los "Hermanos de la penitencia" con su Regla, editada en Roma el año 1479 s5.

\section{d) Aplicación de lo expuesto a las cofradías existentes}

Sin pensar que se van a solucionar todos los problemas de igual manera, ya que cada asociación responde a una forma concreta de pensar y de vivir la fe según sus estatutos y las normas de la Iglesia, hay unos cauces dentro de los cuales hay que buscar solución mediante el diálogo asesorado y los principios no sólo jurídicos, sino también pastorales y teológicos, amén de históricos y sociológicos. Hay derechos adquiridos que conviene y hasta se debe respetar dentro de lo posible, como sucede con algunas cofradías y asociaciones, que tienen personalidad canónica y se tenga civil. La CEE no ve bien que se carezca de personalidad pública canónica y civil. Esto actualmente se reprueba, aunque se reconoce que la misma autoridad jerárquica lo ha sugerido en determinadas circunstancias. Las mismas órdenes y congregaciones religiosas funcionaron en algunas naciones como sociedades civiles. Esto sucedió, por ejemplo, en Venezuela desde 1955 hasta el año de 1964 y aún después ${ }^{56}$.

El Código de 1983 reconoce el derecho fundamental de los fieles para asociarse de modo público o privado. Esta opción no puede negarse a las cofradías penitenciales, si bien es cierto, que por tener culto público $u$ otras finalidades necesariamente públicas, al estar reservadas por su propia naturaleza a la autoridad eclesiástica (c. 301 \& 1) la CEE les exige la personali-

55. 49: Ibid., 56. En Huelva funciona una Hermandad del Santísimo Cristo de la Buena Muerte y Ntra. Sra. de la Consolación y Correa en sus Dolores.

56. Se tituló al principio "Sociedad civil Colegio San Agustín" registrada el 3 de marzo de 1955 bajo el n. 109 del protocolo 1, tomo 3 de la Oficina Subalterna del Tercer Circuito del Registro del Departamento Libertador, Caracas, ff. 140-43. Todavía después de 1964, en el que se hizo el Acuerdo o Modus vivendi entre Venezuela y la Santa Sede, para solucionar los problemas fiscales, se constituyó otra "Asociación civil Benéfico-Docente San Agustín" igualmente domiciliada en Caracas, inscrita en la Oficina Subalterna del Segundo Circuito del Registro del Departamento Libertador del Distrito Federal el 20 de mayo de 1966, bajo el n. 65, f. 201, Protocolo 1 , tomo 2 . Siendo una sociedad benéfico y cultural puede conservar su carácter religioso, penitencial, etc. 
dad jurídica pública ${ }^{57}$. En algunos casos podrá ser privada. También se exige que sea pública para poder tener adscrita una fundación no autónoma (cc. 1303-1304) como ya se observó anteriormente.

Según la actual eclesiología, la relación con la autoridad jerárquica más que para controlar es para fomentar la comunión eclesial. La misma jerarquía no debe cercenar la legítima autonomía de cofradías, sino favorecerla, reconociendo sus aportaciones para conservar un valioso tesoro artístico y sobre todo la fe del pueblo. Esto hay que agradecérselo y estimularles a que sigan siendo fermento cristianizador dentro del Pueblo de Dios y de nuestra sociedad. Una de las mejores maneras de dar participación a los fieles en la Iglesia es a través de las cofradías ${ }^{58}$.

Aunque parezca una redundancia y algo tópico, el fin principal de las asociaciones cristianas y del mismo Derecho Canónico es la salvación de las almas, es decir, la propia perfección y la de los demás. Esto es algo que no hay que perder de vista. Hay que dejar la política al margen de las cofradías, que pueden desempeñar un gran papel también en el orden social. Hay ya bastante bibliografía sobre las asociaciones de fieles que puede ayudar a poner al día las cofradías, archicofradías y pías uniones para que participen en la vida y misión de la Iglesia, como lo establece la exhortación Christifideles laici, donde se reconoce el papel desempeñado por «las confraternidades, Ordenes terceras y los diversos sodalicios. En los tiempos modernos, este fenómeno ha experimentado singular impulso" (n. 20) ${ }^{59}$.

En esta Exhortación se va más allá del Vaticano II y del Código de 1983 al admitir la posibilidad de asociaciones nuevas con fisonomía y finalidades específicas, como las ecuménicas y otras, que tendrán "posibles y comprensibles dificultades" para su actualización y afianzamiento. Se está haciendo un elenco de las pontificias (nn. 30-31) ${ }^{60}$.

e) Normas sobre administración y extinción de asociaciones

Antes de finalizar esta exposición sobre las asociaciones en el Derecho Canónico y Civil; es conveniente hacer algunas observaciones sobre la administración de los bienes. Además del libro inventario de bienes y documentos, debe llevarse un libro de administración de acuerdo con los estatutos, las

57. "Instrucción", n. 7, Boletín de la CEE 3 (1986) 80.

58. Lumen gentium, nn. 30-31; Apostolicam actuositatem, nn. 18-24; Cf. A. M. Rouco VARELA, "Fundamentos eclesiológicos de una teoría general de los derechos fundamentales del cristiano en la Iglesia", Les droits fondamentaux dans l'Église et dans la societé (Friburg 1981) 53-78.

59. JuAn Pablo II, Exhortación "Christifideles laici" 30-XII-1988, Ecclesia 49 (1989) 203.

60. 49. Ibid., 203-204. 
normas canónicas (c. $1283,2^{\circ}$ y $3^{\circ}$ ) y las civiles o concordadas. Las asociaciones, que tienen solamente personalidad jurídica civil, han de regirse por la legislación estatal correspondiente, teniendo un tratamiento especial las declaradas de utilidad pública ${ }^{61}$.

Si la cofradía es persona jurídica pública, al ser sus bienes eclesiásticos, debe ajustarse a la normativa del libro $\mathrm{V}$ del Código, dentro de lo posible, con su consejo de asuntos económicos (c. 1280) o dos consejeros por lo menos, que conforme a los estatutos, ayuden al administrador y le asesoren para el cumplimiento de su gestión. Los deberes del administrador se especifican en los cc. 1283-1284 ${ }^{62}$.

Los estatutos deben determinar los actos de administración ordinaria y extraordinaria (c. $1281,2^{\circ}$ ). En caso de no decir nada los estatutos hay que atenerse a lo dispuesto por la Conferencia Episcopal Española conforme a los cc. 1277 y 1292, como se hace en el Segundo Decreto General del 1 de diciembre de 1984, art. 16: "En orden al cumplimiento de lo establecido en el c. 1277 , han de considerarse como actos de administración extraordinaria: $1^{\circ}$ los expresamente declarados tales con carácter general $\mathrm{o}$, para entidades determinadas, por su propio derecho. $2^{\circ}$ Cuando modifican sustancialmente o suponen un riesgo notable para la estructura del patrimonio de la entidad eclesiástica correspondiente. $3^{\circ} \mathrm{La}$ inversión de dinero y los cambios de las inversiones hechas, siempre que supongan alteración notable en la naturale-

61. J. L. DE LOS Mozos, "Legislación española sobre asociaciones", 296-97. En caso de asociaciones internacionales hay que tener en cuenta el Derecho Internacional además del canónico con el Derecho comparado. Cf. J. M CUESTA, "Legislación civil extranjera sobre asociaciones reliosas y sobre civiles confesionales", Asociaciones canónicas de fieles, 323-38. Para cuestión de impuestos ver M. MIER MENES, "El impuesto sobre sociedades: Su aplicación a la Iglesia Católica", El Derecho patrimonial canónico en España (Salamanca 1985) 349-81.

62. F. R. AzNAR GIL, La administración de los bienes temporales de la Iglesia (Salamanca 1984) 202-207. En la p. 34, este mismo autor reconoce que "después de la promulgación del Código de Derecho Canónico de 1983, bastantes personas jurídicas, ya constituidas anteriormente, pueden ser personas jurídicas privadas eclesiásticas según la actual legislación eclesiástica. Y, por lo tanto, sus bienes temporales, que antes tenían la consideración a todos los efectos de eclesiásticos, pasarán a ser bienes privados. Esto se puede aplicar a los bienes de las cofradías, que eran personas públicas y pasan a ser privadas". Esta problemática con la evolución de las normas sobre esta materia la ha desarrollado ampliamente el mismo autor en "Los bienes de las asociaciones de fieles, en el ordenamiento canónico", Asociaciones canónicas de fieles, 143213, donde reconoce especialmente en la p. 212 al tratar de la intervención de la autoridad eclesiástica para ejercer la vigilancia según el c. 325 \& 1 y otras normas sobre las asociaciones privadas con personalidad jurídica que "queda, en cualquier caso, planteado el grave problema de la falta de claridad y precisión de estas normas. [En cuanto a las] asociaciones privadas sin personalidad jurídica: la autoridad eclesiástica tiene potestad patrimonial sobre ellas, no en cuanto a tal asociación, puesto que no es persona jurídica canónica, sino sobre sus dueños como condueños y coposeedores (c. 310). Su situación, por consiguiente, se equipara a las denominadas asociaciones laicales del CIC de 1917, con toda la problemática que ello entraña". 
za de los bienes que se invierten o riesgo grave para la inversión, cuando el valor exceda el límite mínimo fijado por la Conferencia Episcopal a efectos del c. 1292. Se presuponen actos de administración ordinaria los incluidos expresamente en el presupuesto anual, una vez aprobado en forma ordinaria" ${ }^{63}$.

En España se había fijado por la Conferencia Episcopal, en su Primer Decreto General del 23 de noviembre de 1983, a efectos del c. 1292, "como límite mínimo la cantidad de 5.000.000,00 de ptas. y límite máximo la de 50.000.000,00 de ptas." 64

Sagrada Congregación para Religiosos e Institutos seculares, el 5 de noviembre de 1984 , a tenor del c. 638 \& 3 y 741 \& 1, ha fijado la cantidad de cincuenta millones, como límite, a partir del cual hay que acudir a la Santa Sede ${ }^{65}$.

Para enajenar bienes comprendidos entre el valor mínimo de cinco millones y el máximo de cincuenta millones o el que periódicamente se vaya estableciendo por la Conferencia Episcopal se requiere permiso del obispo diocesano o de los superiores mayores competentes. Si pasa de cincuenta millones o se trata de exvotos, bienes preciosos y artísticos se requiere además licencia de la Santa Sede (c. 1292 \& 2). Esto se requiere para la validez canónica. A veces se da validez civil e invalidez canónica ${ }^{66}$.

Para la licitud de la enajenación de bienes que excedan la cantidad mínima, se requiere: causa justa, tasación de peritos dada por escrito y observar las cautelas prescritas por la legítima autoridad (c. 1293) ${ }^{67}$.

En caso de que la cofradía sea privada, conviene que tenga en cuenta estas normas y otras del Derecho civil para cumplir mejor con su misión. Algunas pueden servir de orientación. Las cofradías, con personalidad jurídica pública, deben rendir cuenta de su administración todos los años al Ordinario (cc. 319 y 1287) y del empleo de las ofrendas y limosnas recibidas

63. Boletín CEE 2 (1985) 64.

64. Ibid., 1 (1984) 103-102, donde se establece además que "el arrendamiento de bienes rústicos y urbanos, comprendidos en el ca. 1297, se equipara a la enajenación en cuanto a los requisitos necesarios para su otorgamiento".

65. F. CAMPO DEL POZO, "Derecho patrimonial de los institutos de vida religiosa", El Derecho patrimonial canónico en España, 74. Según el c. 638 \& 1 para los religiosos "dentro de los límites del derecho universal, corresponde al derecho propio determinar cuáles son los actos que sobrepasan la finalidad y el modo de la administración ordinaria".

66. J. L. SANTOS DiEZ, "Administración ordinaria y extraordinaria", El Derecho patrimonial canónico en España, 50-55.

67. Ibid., 39-49, donde se hace ver cómo la tasación realizada por peritos, es necesaria para saber si se excede o no de los límites establecidos para solicitar la correspondiente licencia, lo cual puede afectar a la validez del acto con sus consecuencias. 
(cc. 1267 y 1301). Tanto a las públicas, como a las privadas, les obliga el tributo seminarístico (c. 264) si tienen templo y el extraordinario (c. 1263) que puede imponer el Obispo diocesano para subvenir a las necesidades de la diócesis en proporción a sus ingresos. Hay que dar cuenta al Ordinario sobre el empleo de las ofrendas y limosnas recibidas de acuerdo con los cc. 1267 \& 3 y $1301^{68}$.

Hay presunción de que, según el c. 1267, las donaciones hechas a los superiores o administradores, se hacen a la persona jurídica. No pueden rechazarse sin el permiso del obispo o de la autoridad competente, que tiene derecho a controlar si se cumple con su finalidad.

En cuanto a la supresión de las asociaciones públicas ya se dijo que debía ser por la autoridad competente y con causa (c. 320) oyendo a su presidente y demás oficiales mayores. Sobre su extinción hay que seguir la normativa de las personas jurídicas (cc. 120 y 123). Las asociaciones privadas se extinguen conforme a la norma de los estatutos. Pueden ser suprimidas por la autoridad competente según el c. $326 \& 1$, si su actividad es en daño grave de la doctrina o de la disciplina eclesiástica o causa escándalo a los fieles. $\mathrm{El}$ destino de sus fieles se hace según lo establezcan los estatutos "quedando a salvo los derechos adquiridos y voluntad de los donantes" (c. 326 \& 2) ${ }^{69}$.

En la legislación del Código de Dercho Canónico de 1983 sobre las asociaciones hay aspectos muy positivos, dando mayor participación y autonomía a los laicos en las asociaciones privadas. Esto puede contribuir a despertar ese coloso dormido o en letargo de gran parte de nuestro laicado cristiano. A las Conferencias Episcopales y a los obispos les toca abrir cauces a través de los "Estatutos marcos" dando orientaciones sobre las características de los que se presenten para un posible control especialmente pastoral. De acuerdo con la legislación vigente, algunas asociaciones públicas, cuyos

68. F. R. AzNAR GiL, La administración de los bienes, 33-34 y 192-94; "Los bienes temporales", Asociaciones canónicas, 203-205, donde se expone que la vigilancia que se hace sobre los bienes y las asociaciones privadas no constituidas en persona jurídica eclesiástica según los cc. 305 y 325 es similar a la que se tiene sobre los fieles cristianos en general. Cf. F. CAMPO DEL Pozo, "Derecho patrimonial de los Institutos" 70-72. Cf. H. SCHWENDENwEIN, Das neue Kirchenrecht, 431-32. Hay que respetar los derechos adquiridos y voluntad de los donantes (c. 326 \& 2. Cf. L. de Echeverría, "Fundaciones piadosas", 114-24; y J.L. de los Mozos, "Legislación española sobre asociaciones", 295-96. Sobre esto hay abundante bibliografía.

69. El caso de las asociaciones privadas sin personalidad jurídica se equipara un poco a las denominadas Asociaciones laicales del Código de 1917, que eran las que hạbían sido sólo recomendadas (c. 684). Actualmente, según el c. 299, pueden estas asociaciones privadas ser "alabadas o recomendadas" por la Iglesia sin estar erigidas. La compleja problemática que lleva consigo la disolución de una asociación religiosa puede verse en una sentencia del Tribunal Supremo de la Signatura Apostólica del 22 de agosto de 1987 (Prot. n. 16890/84 CA), de la que fue ponente el Cardenal Castillo Lara y está publicada en la Revista Española de Derecho Canónico 45 (1988) 769-80. 
bienes eran eclesiásticos según el Código de 1917, pueden pasar a ser privadas y sus bienes dejar de ser eclesiásticos, si lo permite la autoridad competente.

Las cofradías siguen siendo una pieza clave para la participación de los laicos en la vida de la Iglesia de acuerdo con la Exhortación de Juan Pablo II, Christifideles, donde se abren nuevas perspectivas al hablarse de asociaciones de carácter ecuménico, como hemos visto anteriormente. Están teniendo bastante éxito las asociaciones de las Águedas con los movimientos feministas y las de las Madres Cristianas, bajo la advocación de santa Mónica, que deben estar federadas ${ }^{70}$.

\section{f) Otras asociaciones o movimientos eclesiales}

No hay una normativa bien elaborada, sino una referencia esporádica e importante en el c. 529 \& 2, donde se dice que "reconozca y promueva el párroco la función propia que compete a los fieles laicos en la misión de la Iglesia, fomentando sus asociaciones para fines religiosos". Este canon es considerado, según ha observado Francisco Navarro Ruiz, por algunos comentaristas, como norma de carácter exhortativo con una interpretación pastoral y ascética, marginando lo jurídico, cuando en su opinión se trata de una norma preceptiva tanto en la forma como en el contenido. En este canon se da el marco legal para los movimientos eclesiales ${ }^{71}$.

En realidad el parágrafo 1 del c. 529 es claramente exhortativo y pastoral, mientras que el parágrafo 2 , donde se encuentra el texto citado, es preceptivo en su formulación, haciendo referencia a la misión de los laicos individual y asociadamente, que debe ser respetada y estimulada por el párroco, en cooperación con el Obispo y el presbiterio diocesano: "Coopere con el

70. La sociedad de Madres Cristianas ha sido impulsada y promovida recientemente en Valladolid y en más de 20 diócesis españolas por el P. Lorenzo Infante de la Torre, agustino recoleto, que ha logrado integrar a más de 50.000 madres cristianas en forma de comunidades o coros de siete, formando todas ellas la Comunidad de Madres cristianas Santa Mónica, erigida como "Asociación pública" (cc. 312-320) con unos Estatutos, aprobados por el Cardenal Suquía, Arzobispo de Madrid, el día 6 de noviembre de 1987. Se podrá hacer luego una confederación de ellas.

71. F. NAVARRo, "Parroquia y movimientos eclesiales", en La Parroquia desde el Nuevo Derecho. Aportaciones del derecho común y particular. Ponencia presentada el día 20 de abril de 1990 en las X Jornadas Informativas de la Asociación Española de Canonistas. Esta asociación tiene personalidad jurídica civil y carece de personalidad jurídica canónica, algo que admitió como normal el Dr. Julio Manzanares, presidente de la misma, para que canonistas no religiosos puedan pertenecer a ella. las relaciones con la jerarquía eclesiástica han sido buenas y cordiales. Estatutos, art. $3^{\circ}$. 
Obispo propio y con el presbiterio diocesano, esforzándose también para que los fieles vivan la comunión parroquial y se sientan a la vez miembros de la diócesis y de la iglesia universal, y tomen parte en las iniciativas que miren a fomentar esa comunión y la consoliden" (c. 529 \& 2). El consejo Pontificio de Laicos destacó en 1.978 la importancia de las asociaciones en la vida de la parroquia, como estructura esencial de formación, lo que exige también una renovación de formas y comportamientos con un reconocimiento de los derechos y deberes de los fieles en la vida parroquial, diocesana y universal de la Iglesia católica. Esto lo ha desarrollado ampliamente Juan Pablo II en Christifideles laici, donde se abren nuevas perspectivas para las asociaciones y otros movimientos eclesiales, según se ha observado anteriormente. Al lado de las asocaciones tradicionales y a veces como retoños de las mismas, han surgido movimientos y asociaciones nuevas con estructuras, finalidades y diferencias bien marcadas y definidas, tanto en su configuración externa, como en sus campos operativos y métodos educativos. En todos ellos debe haber cierta convergencia con una pastoral de conjunto dentro de la misión de la Iglesia ${ }^{72}$.

\section{CONCLUSIÓN}

El Código de Derecho Canónico de 1983 da unos principios orientadores, que a primera vista chocan un poco con la doctrina tradicional, al haber nuevos criterios de calificación, como se da una cierta tensión en el fenómeno asociativo-religioso dentro de los ordenamientos civiles actuales con separación de Iglesia y Estado. Hay nuevas tendencias interpretativas de los principios rectores de la materia. Se están armonizando las diferencias entre el Derecho canónico y el civil a través de acuerdos y concordatos, que respetan los principios de libertad religiosa y la libre asociación con cierto control civil eclesiástico.

En el ordenamiento canónico se da mayor relevancia a las que tienen personalidad jurídica pública, mientras que los ordenamientos civiles suelen favorecer'a las asociaciones declaradas de utilidad pública, por lo que pueden disfrutar de ciertos beneficios o prerrogativas de índole fiscal y administrativo, como las exenciones, subvenciones, etc.

Las asociaciones religiosas católicas, además de la normativa canónica que varía según sean públicas y privadas, han de atenerse a lo dispuesto por la Conferencia Episcopal y legislación civil local, nacional y concordada. Al reconocerse el derecho fundamental de asociación, tanto a nivel canónico

72. J. B. BEYER, "Motus ecclesiales", Periódica 75 (1986) 613-37. Es bueno el trabajo de J. Bogarin Díaz, "Los movimientos eclesiales en la VII Asamblea General Ordinaria del Sínodo de Obispos", Revista Española de Derecho Canónico 47 (1990) 69-135. 
como civil, los fieles cristianos pueden asociarse libremente mediante un acuerdo privado entre ellos con fines religiosos particulares, quedando en la categoría de "privadas" o para promover el culto público y la evangelización en nombre de la Iglesia, por lo que han de constituirse en personas jurídicas públicas. Algunas cofradías, que eran personas jurídicas públicas y tenían edificios, como templos y capillas, considerados bienes eclesiásticos, difícilmente podrán pasar a ser asociaciones privadas sin desprenderse de esos bienes o sin llegar a acuerdos con. la autoridad eclesiástica correspondiente ${ }^{73}$.

Siempre será necesario tomar una serie de cautelas o medidas estatutarias para saber a qué atenerse y obtener la aprobación eclesiástica y también la civil, si se considera necesaria o pertinente. Tanto las asociaciones privadas, como las públicas, deben tener sus estatutos propios con los fines, objetivo religioso o social de la asociación, su sede, el gobierno y las condiciones para formar parte de ellas, lo mismo que su modo de actuar, atendiendo a la necesidad o utilidad de tiempo y lugar (c. 304 \& 1). Todas las asociaciones de fieles, privadas y públicas, están bajo la vigilancia de la autoridad eclesiástica competente, que es mayor en las públicas, por su mayor responsabilidad y vinculación a la Iglesia. Esta vigilancia es principalmente para conservar la integridad de la fe y buenas costumbres, así como para evitar que se introduzcan abusos en la disciplina eclesiástica (c. $305 \& 1)^{74}$.

73. F. CAMPO DEL POZO, "Problemática canónica y civil de las cofradías penitenciales en España", comunicación presentada en el II Encuentro de Cofradías Penitenciales de España, el día 30 de septiembre de 1989, en el Seminario de Calatrava, y publicada parcialmente en Adelanto (Salamanca) n. 32. 653 del día 2 de octubre de 1989, p. 10. El coloquio resultó interesante y varios asistentes presentaron diferentes problemas, como el de que algunos obispos se negaban a reconocer la personalidad jurídica privada de las cofradías alegando que tenían que ser públicas por razon de su culto público o porque tenían bienes eclesiásticos. Algunas, sin personalidad jurídica canónica, habían logrado el reconocimiento civil con la presentación de los mismos estatutos en el Gobierno Civil de su provincia. Como observa acertadamente el profesor Federico R. Aznar Gil, el tema de los bienes de las asociaciones canónicas es secundario en el conjunto de la amplia problemática que presentan dichas instituciones eclesiásticas. "Los bienes temporales de las asociaciones", Asociaciones canónicas, 143 y 206. Esto mismo lo defienden varios canonistas, como el buen autor y profesor, Mariano López Alarcón sobre "La titularidad de los bienes eclesiásticos", El Derecho Patrimonial Canónico, 9-31. Él pide a la jerarquía de la Iglesia española que ofrezca garantías y una vigilancia razonable sobre los bienes de las asociaciones privadas. "Si la Iglesia se desentiende de estos bienes y de su tutela, buscarán esa protección en el Estado o en otros organismos civiles, lo que contribuirá a fomentar su secularización" (ibid., 20). Coincide con el profesor $\mathbf{H}$. Schmitz, en que hay que respetar la libertad asociativa de los fieles en sus distintas formas de cooperación religiosa. "Das kirchliche Vermögensrecht als Aufgabe der Gesamtkirche und der Teilkirchen", Archiv für katholisches Kirchenrecht 1 (1977) 25. Pueden existir asociaciones con personalidad jurídica civil.

74. En las conclusiones del II Encuentro de Cofradías Penitenciales se pidió a la jerarquía eclesiástica, especialmente a los obispos, "que las declaraciones teóricas en favor de las cofradías tengan una traducción práctica, a fin de que no queden marginadas dentro de la Iglesia". 
Es legítimo que deban observarse una serie de cautelas para obtener la aprobación o autorización, que en España debe completarse y revisarse a tenor de lo acordato y lo dispuesto en la Ley del 15 de julio de 1983, sobre el derecho de reunión. Los organizadores son los responsables, ante el ente público, solidariamente. Cada uno es responsable de sus propios actos y en parte de los de la organización a la que pertenece, variando entre las privadas y las públicas incluso a tenor de la legislación canónica, ya que las públicas actúan en nombre de la Iglesia. Algo que no distinguen fácilmente o no ven claro los simples fieles, para los que las asociaciones religiosas privadas, aprobadas por la Iglesia, acúan de algún modo vinculadas a la jerarquía eclesiástica, como ha reconocido la Conferencia Episcopal Española. Habría que clarificar también lo que se entiende por "promover el culto público" en los cc. 298 \& 1 y 301 . El hecho de asistir a una procesión o participar en ella no quiere decir que se tenga como fin siempre el promover el "culto público". Podría seguir llamándose cofradía o hermandad una asociación, según el c. $304 \& 1-2$, con personalidad jurídica privada. Debe respetarse la voluntad de los fieles, que desean continuar con sus antiguas cofradías actualizadas, pías uniones, como la de Santa Rita, y asociaciones como la de las Madres Cristianas de Santa Mónica y otras movimientos ${ }^{75}$.

Fernando CAMPo del Pozo

Norte de Castilla (Valladolid) n. 51.551, del 2 de octubre de 1989, p. 13. Las conclusiones han sido ampliamente difundidas. Sorprende que tanto los Obispos del Sur de España, en su Carta Pastoral sobre Las hermandades y Cofradías, (Madrid 1988) 21, lo mismo que el "Directorio diocesano de las Cofradías de Semana Santa", Boletín Oficial del Arzobispado de Valladolid 115 (1991) 67-78 y otros Directorios no mencionen la posibilidad de cofradías y hermandades con personalidad jurídica privada o sin ella, como se reconoce en los cc. 321-326 del Código de 1983.

75. La atención a las asociaciones modernas, como es el caso de los grupos carismáticos, neocatecumenales y otros en iglesias regentadas por agustinos no debe ser en detrimento de las asociaciones agustinianas y otras con raigambre tradicional, como sucede con las cofradías penitenciales, Madres Cristianas, etc. Sus orientaciones teológicas deben ser recogidas en normativa canónica. Cf. R. BlazQuez, Las comunidades neocatecumenales. Discernimiento teológico (Bilbao 1988) y "Carta del papa sobre las comunidades neocatecumenales" Ecclesia del 29 de diciembre de 1990, n. 2.508 (1990) 35-37; F. CAMPo DEL Pozo, "Las asociaciones en el Derecho canónico y civil" Revista Española de Derecho Canónico 46 (1989) 487-511, donde se recoge la mayor parte de lo aquí expuesto tal como se presentó en el II Encuentro de Cofradías Penitenciales, celebrado en Salàmanca del 29 de septiembre al 1 de octubre de 1989. 